\title{
(IN)FERTILE GROUND? SOCIAL FORUM ACTIVISM IN ITS REGIONAL AND LOCAL DIMENSION
}

\author{
Peter J. Smith \\ Centre for State and Legal Studies \\ Athabasca University \\ jays@athabascau.ca \\ Elizabeth Smythe \\ Department of Political Science \\ Concordia University College of Alberta \\ elizabeth.smythe@concordia.ab.ca
}

\begin{abstract}
Since its inception in 2001 World Social Forum (WSF) has grown in numbers and drawn activists from all areas of the globe. It has also spawned a myriad of social forums around the world. But the pattern of participation within the WSF global event or within other forums has not been evenly spread in geographic or spatial terms. This chapter examines how and why social forum activism emerged in some places and not others. We map the social forum from the first WSF in 2001 through its proliferation and fragmentation over time as it has taken root at various levels-continental, national, regional and local. Then we provide comparative case studies of sub-global forums drawn from North and South America, Europe and Africa. We also compare different manifestations of social "forumism" along a number of dimensions. Drawing on comparative politics and its emphasis on the specifics of place and the role of context we discuss these patterns and the factors that might account for why these forms of resistance find barren or fertile ground around the world.
\end{abstract}

\section{INTRODUCTION}

When the first World Social Forum was held in Porto Alegre Brazil in January 2001 to coincide with the meeting of the World Economic Forum and challenge neo-liberal globalization with the slogan "Another World is Possible", few would have predicted the rapid growth in the number of activists who gather at the annual (and now bi-annual) global event. Few also would have foreseen the proliferation of forums since then ranging from very local (e.g. neighborhood, community) to regional, national and continental ones (Glasius and Timms 2006). Even more forums have been organized around themes (such as education) and shared identities (gender, ethnicity). This expansion of social forum activism, however, has been uneven, both in terms of who participates in forums, or where geographically sub-global forums emerge. This article addresses the question of where social forum activism has emerged and why. It examines some of 


\section{JOURNAL OF WORLD-SYSTEMS RESEARCH}

the mechanisms by which social forum activism has diffused globally as an innovative form of collective action. ${ }^{1}$

While the study of social movement innovation is not new much of it has focussed on the mechanisms by which innovations spread and networks of activists link up. Less attention has been paid to where innovation diffuses to, and most importantly, as Soule (2003) has pointed out, why it takes roots in some places and not others. Explaining the shift of scale in collective action from the local to the global has also been a major focus of analysis (Tarrow and McAdam 2005) but how global collective action stimulates a new form of globally-informed local activism has been a subject of less analysis. Moreover, while those studying the global justice movement (GJM) have seen the emergence of the WSF as an important development, their analyses have centered on who is excluded and included in its processes, its innovative structure and internal tensions (Juris 2008). Less attention has been paid to the role of place and context in shaping the nature of social forum activism at various levels or scales. ${ }^{2}$ Why social forum activism spreads from global to local forums and the transmission mechanisms by which this occurred need to be investigated.

We begin then with a discussion of our data and a description of the pattern of social forum activism we found looking at those geographic regions where adoption has been extensive and where it has not. We discuss possible explanations for this pattern of diffusion and begin, through descriptions of social forums at various levels, to try to understand the role of place and political opportunity structures (Meyer 2004) in providing fertile ground for these innovations. Our intention is not to provide definitive explanations of why and how social forum activism does, or does not, imbed itself in every place and space; rather, our goal is to raise questions that future case studies might address.

\section{METHODOLOGY}

We began with the question of who participates in social forums and where forums occur. Data on numbers and origins of participants at WSF events are drawn from WSF secretariat and other reports. For other social forum activity we tried to find all those events and processes that self identified as a social forum or referenced the WSF or another forum, such as the European Social Forum (ESF). The search included listings contained in the on-line Bulletin of the WSF, a search of the Internet using translated key words in English, Spanish, French, Portuguese and Italian, supplemented by secondary sources describing forums and other mapping efforts and studies (Glasius and Timms 2006).

\footnotetext{
${ }^{1}$ This article is not a critique of the social forum process. For an analysis of the WSF as a space of contestation and contested space see Jackie Smith, Marina Karides, et. al. (2007) Global Democracy and the World Social Forums. Boulder, CO.: Paradigm Publishers.

2 An exception to this is Janet Conway "Reading Nairobi as Place, Space, and Difference." Sociologists without Borders 3(1): 48-70.
} 
We classified the geographic scale ranging from the global to the local as follows:
1 Global
5. National
2. Inter-continental
6. Sub-national
3. Continental
7. Local
4. Regional

The local level included urban areas and, in some cases, neighborhoods within large urban areas. Reliance on the Internet and secondary sources and the languages used means that some social forums may have been missed, especially those without online access, particularly in the Middle East and East Asia. The absence of structure, continuity or institutional memory in some of these networks means we are providing a partial view, a snapshot in time.

Social forums also vary in their goals and structures. Some form ongoing networks, with meetings, on-line exchanges or other activities, while others are clearly oriented to a project of organizing a discrete forum event. Data included both types along with the number and range of themes or issues addressed. Single theme forums, such as those dealing with education or health, have become more common since 2001. We also discovered a number of forums organized around identity (eg. gender or ethnicity) rather than an issue or theme. Over 600 events and organizations for which a minimum of information was available were identified. Of those, 411 have been coded to date for details about the event or organization. The balance had incomplete or partial information.

\section{PATTERNS OF SOCIAL FORUM ACTIVISM: WHERE?}

Table 1: Growth of the global WSF since its inception in 2001 to 2007 (total participants).

\begin{tabular}{lll} 
Year & City, Country & Number of people \\
\hline 2001 & Porto Alegre, Brazil & 20.000 \\
2002 & Porto Alegre, Brazil & 50,000 \\
2003 & Porto Alegre, Brazil & 100,000 \\
2004 & Mumbai, India & 115,000 \\
2005 & Porto Alegre, Brazil & 155,000 \\
2006 & Polycentric -Total & 127,000 \\
& Caracas, Venezuela & $72,000^{*}$ \\
& Bamako, Mali & 25,000 \\
& Karachi, Pakistan & 30,000 \\
2007 & Nairobi, Kenya & $57,000^{*}$ \\
2009 & Belem, Brazil & 115,000
\end{tabular}

Source: IBASE- World Social Forum: An X-Ray of Participation in the Policentric Forum 2006 p 13 (available at www.ibase.br) and Bulletin of the WSF March 12, 2009

*Estimated data 


\section{JOURNAL OF WORLD-SYSTEMS RESEARCH}

As Table 2 suggests proximity is clearly a factor in who participates in the global event. In 2005 most were drawn from surrounding regions, a reflection of distance and costs of travel.

Table 2: WSF 2005 participants by geographical origin

\begin{tabular}{ccc} 
Continent & National origin & Percent \\
\hline Total Participants & 92,281 & 100 \\
Brazil & 73,856 & 80.0 \\
Rest of the world & 18,425 & 20.0 \\
Latin America (without Brazil) & 8,083 & 8,8 \\
Europe & 4,154 & 4.5 \\
USA/Canada & 2,376 & 2.6 \\
Asia & 2,266 & 2.5 \\
Africa & 1,474 & 1.6 \\
Oceana & 72 & 0.1 \\
\hline
\end{tabular}

Source: IBASE - World Social Forum : An X-Ray of Participation in the Policentric Forum 2006. Data is based on $59.5 \%$ of those registered for the WSF.

Forums held in Caracas, Venezuela and Bamako, Mali in 2006 show a similar pattern where between 65-72 percent of participants were nationals of the host country with 90 per cent of participants drawn from the surrounding continent (IBASE, 2006).

While WSF participants are drawn mostly from surrounding regions the events attract participants from many countries-132 in 2005, according to the WSF secretariat. Surveys conducted by the Brazilian NGO IBASE and a number of academics (Chase-Dunn et al. 2006; Brunel 2006) confirm 163 cities around the world were represented. Those coming from a distance are fewer in number and drawn from groups or classes that have access to resources and time to attend such events. However, the pattern of their attendance at global events cannot be accounted for solely by distance or cost, as Table 3 indicates.

If distance alone accounted for participation levels why would participants from France outnumber those of Mexico at the Venezuelan forum and those of Germany at the Mali forum? Even more puzzling is why U.S. participation is lower than that of Canadians at the Mali forum. Other factors are at work including the relative strength of the social forum process in each country.

Once we examine the broader range of social forums at various levels another interesting pattern emerges. As the chart below indicates Continental Europe, particularly France and Italy, and South America, especially Brazil, have been social forum hotbeds. 
Table 3: Polycentric WSFs 2006 by nationality of participant (in \%)

\begin{tabular}{llll} 
& Venezuela & Mali \\
\hline Countries & $\%$ & Countries & $\%$ \\
\hline Venezuela & 65.0 & Mali & 72.3 \\
Columbia & 10.8 & Guinea & 3.7 \\
Brazil & 5.5 & Senegal & 2.0 \\
Argentina & 4.1 & Nigeria & 1.7 \\
Chile & 2.1 & Burkino Faso & 1.6 \\
Mexico & 0.3 & France & 3.3 \\
France & 0.7 & South Africa & 1.0 \\
Germany & 0.3 & Germany & 0.1 \\
United States & 2.2 & United States & 0.2 \\
Canada & 0.9 & Canada & 0.5 \\
Other Countries & 13.9 & Other countries & 13.6 \\
\hline
\end{tabular}

Source: IBASE (2006) the World Social Forum: An X-ray of participation in the polycentric forum, 2006, Caracas and Bamako chapters (www.ibase.br).

\section{Chart 1: Totals for all Fora per Continent}

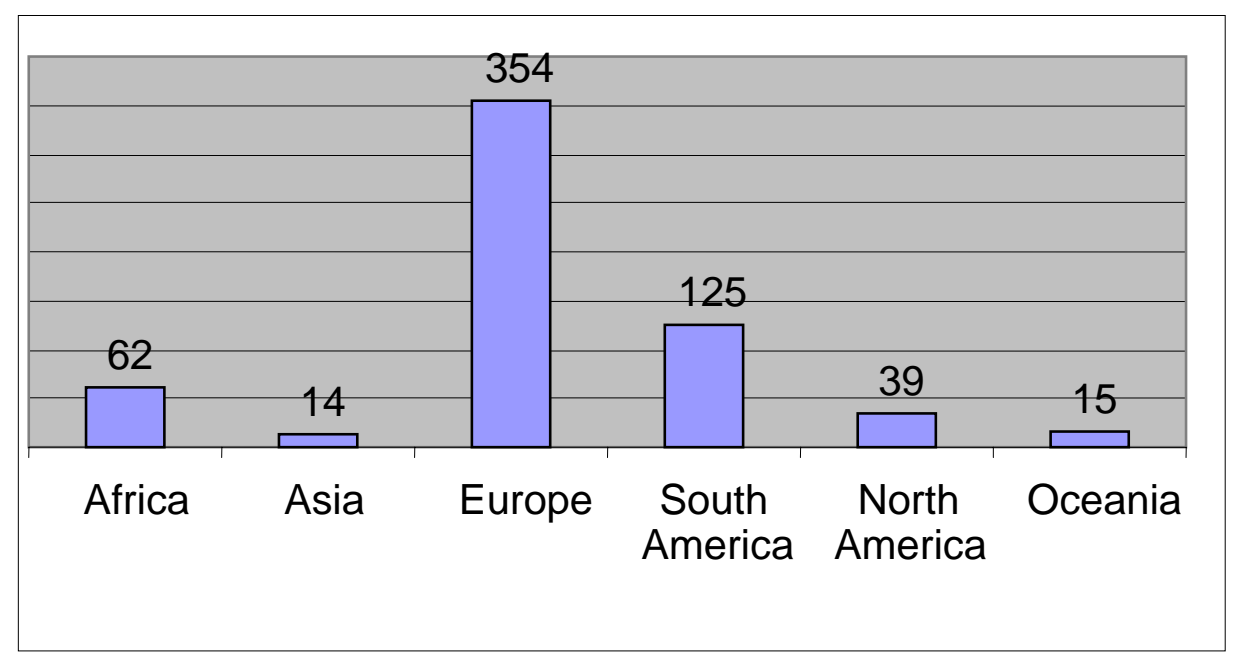

A second pattern emerges when we separate out social forum organizations or networks (chart 2) from the total number of all social forums ${ }^{3}$ (chart 1$)$.

\footnotetext{
${ }^{3}$ The number of organizations exceeds the number of events since some organizations did not hold any events at all.
} 
Chart 2: Number of Social Forum Organizations per Continent

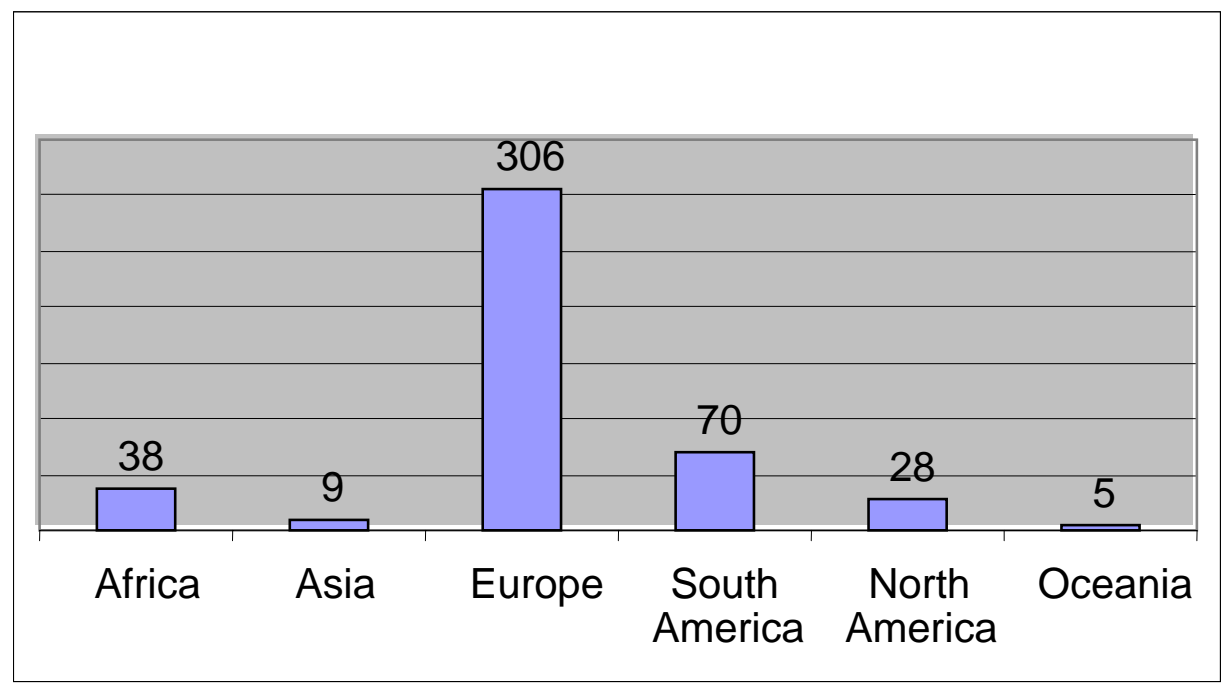

South American social forumism is more tied to holding events than is the case in Europe, especially Italy, where the number of social forum organizations dwarfs the number of forum events or gatherings held.

\section{Chart 3: Total Forum Events per Continent}

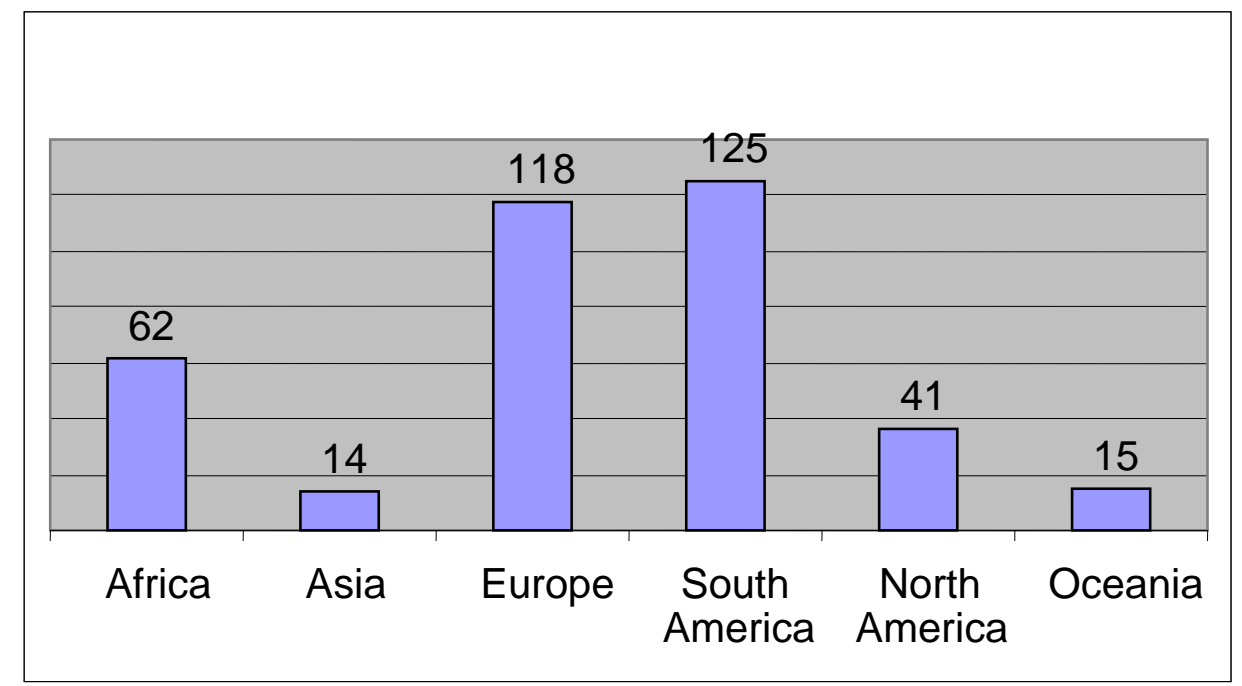

Numbers of events do not tell the whole story however, since they do not reflect how many participants were involved. While our data on attendance is limited we do know that it varies widely from forums in Africa with only a few hundred participants, even for continental events, 
to neighborhood forums in cities such as Sao Paolo, Brazil which draw tens of thousands of participants.

As Chart 4 indicates the global-local balance has also shifted with over half of the social forums since 2001 occurring at the national level or below.

Chart 4: Social Forums by Scale

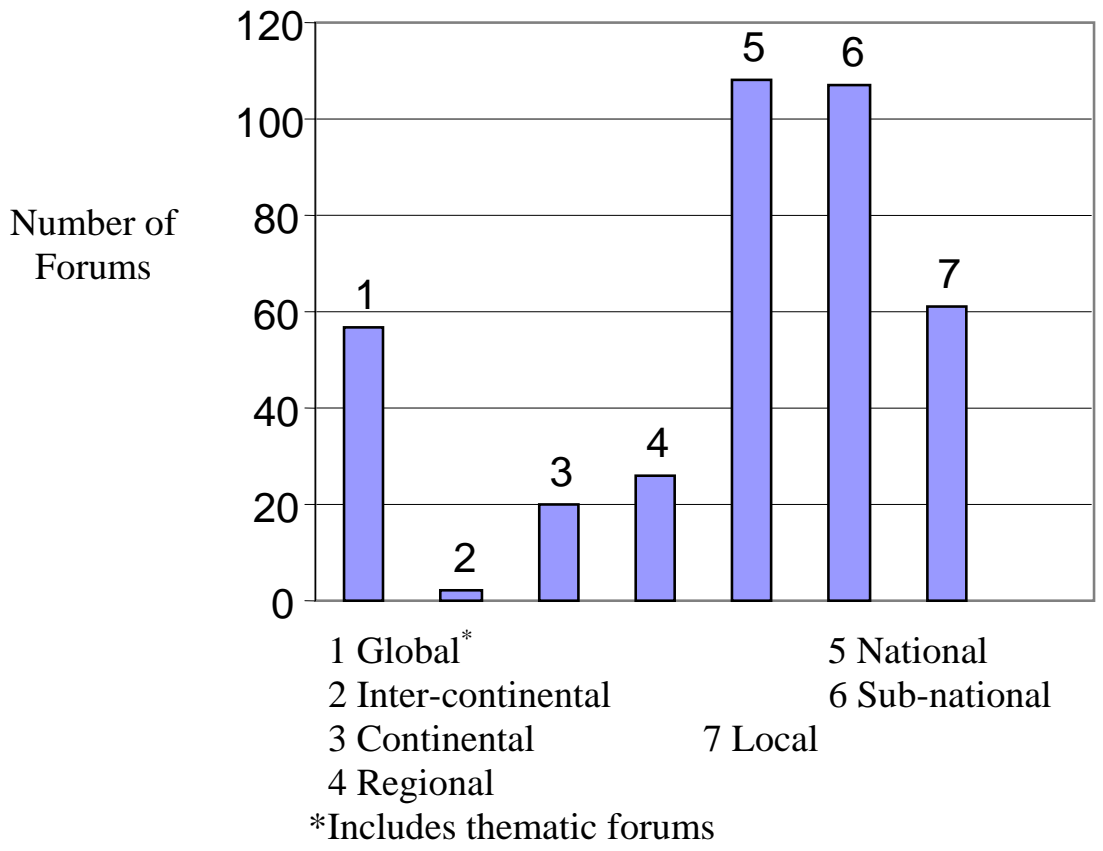

\section{PATTERNS OF SOCIAL FORUM ACTIVISM: WHY?}

The most interesting question is why these patterns occur? What precipitates social forum activism? Corporate globalization has impacted virtually every area of the globe, albeit unevenly, ranging from the loss of employment, or its growing precariousness, to cuts in social services, social exclusion, environmental degradation, and human rights violations. Why is the response to these global forces different in terms of where the activism occurs?

Studies of diffusion, defined as the flow of social practices (Soule 2003; Chabot 2001), have identified a process involving the transmission of innovative practices through various channels, both direct and indirect, to those adopting the practices. Direct channels include social networks through which communication, the transfer of resources and ideas could occur. More indirect channels include the adopter developing a sense of shared identity (perhaps involving a 


\section{JOURNAL OF WORLD-SYSTEMS RESEARCH}

master frame ${ }^{4}$ ) with a more passive transmitter and /or becoming aware of these practices through agents such as the media. The adoption of these practices is not a given, however. Which practices are successfully diffused and how they become locally imbedded and adapted are more interesting and complex questions, and require attention to the place and context of adoption. Given that social forum events, in particular, require organizational capacity, resources and the space to resist suggests that the political opportunity structure (McAdam 1996) ${ }^{5}$ at the national or sub-national level, the mobilization of resources and the strength of existing old and new social movements will be important factors. Geographic regions peripheral to centres of power in the global system may lack resources and while resistance to the impact of globalization might emerge there is also a strong likelihood of repression (Smith 2004). Thus the relative absence of both resources and political opportunities may account for the lack of social forum activism in Africa, in comparison, for example, to Europe or South America.

Direct transmitters include the International Council (IC) of the WSF and the secretariat which, after the second WSF, sought to encourage and facilitate the organization of continental, thematic and local forums in Asia and Africa, seen as under-represented in the WSF process. Information, financial resources (some from foundations and NGOs) and technical assistance have all been provided in the context of decisions to move global WSF events to Mumbai, India in 2004, various cities in Africa, South America and Asia in 2006, and Nairobi, Kenya in 2007. All were intended to provide opportunities for those in the regions to participate in a WSF, but also to stimulate regional and local activism networks.

The development of social forums, as with other forms of transnational resistance, is also tied to global events or organizations. Pianta (2005) argues that UN World Summits played a role in the development of transnational civil society networks. Similarly key meetings of international institutions (WTO, IMF, G8) seen to embody neo-liberalism have stimulated social forum forms of resistance. Other channels of direct diffusion include individual activists who have attended a WSF or continental event and return to their place of origin to "report back" to the group or network to which they belong. Inspired or stimulated by their experience, they then seek to create a similar local process or event. When an event engaged in anti-neoliberal activities pre-dates the WSF, but then transforms itself into a social forum event after the fact as a result of a shared identification, indirect diffusion has occurred. Transmission alone does not guarantee successful diffusion, nor does it suggest that practices are uniformly adopted at either a continental, national or local level. We illustrate this with multilevel cases drawn from various continents which look at both broad patterns of social forum activism.

\footnotetext{
${ }^{4}$ Frame refers to the social construction of meaning or interpretation used by collective actors to convince people to take collective action. For many in the Global Justice Movement neoliberal globalization represents the "master frame."

${ }^{5}$ By political opportunity structure we mean how open or closed domestic or international institutions are to collective actors (social movements). Political structures, including their degree of access and political responsiveness, along with level or type of repression can expand or limit a collective actor's opportunities. Groups that perceive threats from domestic opportunity structures or find them closed may seek out more open international institutions (eg. the United Nations) or create their own opportunity structures (eg, the WSF) as a means of pressuring domestic structures to be more responsive to their demands.
} 


\section{Social Forums in the North: North America}

Relatively few social forums events have been held in North America compared to Europe and South America. That said, within North America there is a great deal of variation. Despite having one tenth the population Canada has had a similar number of sub-national social forums (20) as the United States (21). In contrast only five social forums have been held in Mexico. Two of these were not Mexican events per se, the 2003 Cancún "Peoples Forum for an Alternative to the WTO" and the 2006 Southwest Border Forum. However, a large-scale event was recently held in the Zocalo in Mexico City as part of the global day of decentralized WSF actions in January 2008.

Patterns of national attendance at global WSF events reflect similar trends. Data show that Americans and Canadians outnumber Mexicans attending global WSF events, in Canada's case rising from over 250 in 2003 to almost 700 in 2005 (Conway 2006; Hadden and Tarrow 2007) Canadians participating in the 2005 youth camp outnumbered those of the US and Mexico. Although Mexico is proximate to Venezuela, site of the 2006 Polycentric Social Forum, perhaps due to the relatively high cost of airfare for Mexicans, only $0.3 \%$ of the participants were of Mexican origin, in contrast to .9 for Canada and 2.2 for the US. (See Table 3) On the other hand participants from Argentina, a much greater distance to travel than Mexico, but where the social forum tradition is stronger, composed $4.1 \%$ of participants. Mexico, on the face of it, would seem to be a natural home for the social forum process but, in fact, is not. This is curious for, as Wallerstein notes, the Zapatistas "have remained an iconic movement with the WSF, a sort of inspirational force” (2008: 3). For example, the Abruzzo Social Forum in Italy, itself a catalyst for other local Italian social forums, mentions Chiapas 22 times and Zapatistas 16 times on its website (Abruzzo Social Forum).

The relative dearth of social forums in Mexico lies in the complexities of state-society relations, the strengths and weaknesses of collective actors, and the current state of political activism in Mexico. Of particular salience is that Mexico is increasingly fragmented by region, the richer north versus the poorer center and south, by class, and by ethnicity/indigeneity. The left today in Mexico is also divided between the non-institutionalized left and the more institutionalized left which, in turn, is itself divided. (Quintana 2006; La Botz 2005; Icaza 2008) The refusal by the Zapatistas to endorse López Obrado of the Party of the Democratic Revolution in the 2006 presidential campaign or participate electorally in favour of the "the other campaign" to mobilize the excluded has been criticized by others on the Mexican left for sectarianism and perhaps contributing to the victory of the right wing National Action Party's (PAN) candidate Felix Calderon. All this has occurred in a context of repression and violence in Mexico that inhibits grassroots organizing and social protest. Social forum organizing in Mexico faces more obstacles and restrictive political opportunity structures than in some other Latin American and European countries.

What factors might account for variations in social forum activism in Canada and the United States? In Canada there are significant differences between English Canadian and Quebec social forum activism attributable to historical differences in state-society relations, political opportunity structures, nationalism, and the role of important civil actors such as unions. For most English-Canadian activists in the 1980s and 1990s free trade and neo-liberal globalization represented a threat to Canadian identity and sovereignty. For civil society forces in Quebec, including the labor movement, globalization and free trade, in contrast, represented an 


\section{JOURNAL OF WORLD-SYSTEMS RESEARCH}

opportunity for Quebec to promote its nationalist project. Thus while English Canadians activists fought unsuccessfully against the Canada United States Free Trade Agreement (1989) and the North American Free Trade Agreement (1993) in Quebec for much of the 1990s the prosovereignty governing Parti Québécois (PQ) "was supported by all unions ... and major social groups” (Dufour 2003:17).

At the federal level in English Canada state-society relations were re-engineered during this period by successive neo-liberal governments re-framing citizens as consumers, greatly reducing political opportunity structures for civil society actors. "The result," claims M. Smith, was a demonstrable "decline of the domestic nation-state as the site of democratic contestation and political life." (2005:180) In Quebec, on the other hand, as opposition (lead by youth and feminists) to free trade and neo-liberal globalization emerged in the late 1990s against the Multilateral Agreement on Investment (MAI) political opportunity structures at the provincial level remained open. Even as activists questioned the PQ's stance on free trade and globalization the government continued to promote an international presence, including NGOs supportive of the WSF process such as Alternatives. According to Dufour and Conway (this volume) with NGO, government, political party and union support eighty per cent of the 700 Canadian WSF 2005 participants came from Quebec, including a sizable youth contingent. Youth, including those that attended the WSF, have been instrumental in diffusing the social process to Quebec, advocating on its behalf and providing a horizontalist vision of the WSF process. In 2007 the Quebec labor movement, facing reduced access to power as the result of a new Liberal government, dropped its reluctance to support the Quebec social forum process and cooperated with autonomist youth activists to stage a successful Quebec Social Forum with 5,000 participants.

Nothing analogous has occurred in English-speaking Canada. Large anti-corporate NGOs, such as the Council of Canadians, and national unions have been very visible at the global WSF but less so in the social forum process in English Canada thus depriving it of considerable energy and resources. According to Conway,

the agenda of localizing the Social Forum has been taken up in a variety of ways, at a variety of scales, but most often by an ad hoc group of activists ... coming from diverse movement experiences and cultures. ... In virtually every Social Forum process in Canada, the labour movement, as a movement, has been notable by its absence. (2006:10)

The United States has had 21 social forums including the US Social Forum in June/July $2007 .{ }^{6}$ U.S. sub-national forums appear in a narrow band of localities situated in the Northeast and Midwest. In partisan politics these tend to be "blue states", centres of a more progressive political tradition. That, however, does not explain social forum absence in the coastal Northwest U.S., which is also "blue". A Northwest forum planned for October 2004 collapsed "when First Nations participation withdrew, citing conflicts over the pace and nature or decision-making." (Conway 2006:10)

\footnotetext{
${ }^{6}$ According to Jeffrey Juris there was a San Francisco Forum in 2002 raising the number to 20. Communication March 1, 2007 presentation International Studies Association, March 1, 2007.
} 
The Northwest Social Forum's inability to negotiate the tricky shoals of identity politics (Center for Communication and Civic Engagement 2007) offers a clue to the absence of more social forums in the U.S. Identity politics also marked the Midwest Social Forum (MWSF). The MWSF was founded in 1983 as a yearly (largely white) Midwest Radical Scholars and Activists Conference engaged in activities of challenging neo-liberalism pre-dating the WSF. Renamed RadFest in the late 1990s it became the MWSF in 2003, an example of diffusion over time. In 2005 concerned that it was too white it changed from a centralized, hierarchical model to a more grassroots one composed of a minimum of $60 \%$ people of color and $60 \%$ women and representative "with respect to class, age, sexual orientation, ability, issue focus, and ideological or strategic perspective" (Becker 2006). ${ }^{7}$

Similarly the Boston Social Forum, held in July 2004, created a large multiracial network (Pramas 2004) of over 50 environmental, peace, human rights, civil rights, neighborhood, and women's organizations and attracted 5,000 participants, 300 organizations and 600 events. The BSF and the MWSF together suggest that location is very important (both are areas of progressive politics) as well as a grassroots organization reflective of the diversity of left politics in the area. The weakness of the social forum process in the United States is also linked to the changing political opportunity structure in the US post $9 / 11$ and the resulting politics of fear (Juris 2007; Hadden and Tarrow 2007). As Donohue (a BSF activist) indicates:

Daily struggles against new wars, new funding cuts, new court rulings, and new arrests leave activists unable to develop a coherent response to the broad assault on the public sector, civil liberties, civil rights, and international law. (Donohue, 2004 July 7)

Defending the right to dissent in an increasingly authoritarian political environment was of critical importance. The tendency of the U.S. global justice movement to "emphasize mass protests ... with no continuing grassroots mobilization and the lack of strong leftist parties in the US" (Juris 2007:5) limited the organizational capacity of the left to effectively plan and hold social forums. The virtual invisibility of the social forum process in the tightly concentrated U.S. mass media also may have contributed to the lack of social forums. However a very successful US Social Forum was finally held at the end of June, 2007 in Atlanta and was attended by over 11,000 participants. Its success led to a decision of the organizing committee to hold a second one in Detroit in 2010. ${ }^{8}$

\section{Social Forums in Europe: French and Italian Connections}

Within Europe, in contrast to North America, we see a huge number of forums and much variation in number and type particularly in France and Italy. France follows the discrete event model of social forums while Italian forums operated more as a process or network, as did some forums in the UK. One explanation may be the influences of different organizations or types of mobilization and the extent to which social forum innovations are compatible, or resonate with,

${ }^{7}$ On the issue of race and the US Social Forum see Juris, Jeffrey S, (2008) "Spaces of Intentionality: Race, Class and Horizontality,” Mobilization 2009.

${ }^{8}$ For an analysis of the USSF see Jackie Smith et Jeffrey Juris et al 


\section{JOURNAL OF WORLD-SYSTEMS RESEARCH}

these local experiences, ideas, movements and organizations. The role of the Association for the Taxation of Financial Transactions for the Aid of Citizens (ATTAC), a key founding member of the WSF, as an influential network of organizations in France (Waters 2004) may account for what Callincos calls a reformist social forum movement there. He identifies two other forms of European social forum activism, a radical one where the Communist Party in Italy (PRC), the Ligue Communiste Révolutionnaire in France, and the Socialist Workers Party in Britain play a role, and a horizontal, or autonomist strain, dominated by new social movements which is closer to the horizontalist tendency found in social forums. (Lee 2004; Juris 2008).

French and Italian forums also illustrate differences in transmission and the role of changing political opportunity structures. ${ }^{9}$ The French disposition against globalization and the embracing of the social forum process is evident at the regional (department) and local levels where our data indicate the existence of at least 46 social forums since 2002. The Gironde Social Forum (GSF), however, claims that in 2005 there were, by their count, over one hundred local social forums throughout France(GSF 2006). Of the five social forums we profiled in detail, four had close links with ATTAC, the Alpes Maritime Social Forum, the Gironde Social Forum, Pays Nantais Local Social Forum, and the Region 89 (L’Yonne) Social Forum. Any discussion of social forum activism in France then, as well as in the creation of the WSF and other forums (in northern Europe and South Amercia), must address the role of ATTAC.

ATTAC was formed in 1998 after an editorial in Le Monde Diplomatique (LMD) by Ignacio Ramonet calling for the creation of an organization to oppose global finance capital and an appeal by LMD director Bernard Cassen to form an organization advocating for the Tobin Tax to regulate economic processes and support social and human rights. Cassen later helped found the WSF. Expansion to over 40 ATTAC chapters led to the founding assembly of the network in June 2003. (Kolb 2005) Today, in France, Sommier and Combes claim "the global justice movement is largely associated with one organization, ATTAC.” (2007:108). ATTAC's more reformist position and influence in France are due in part to the more open opportunity structure in from 1998-2002 with a cohabitationist government and the Socialist Party dominating parliament. The influence of public intellectuals in France and ATTAC's link to LMD and socialist intellectuals also gave it extraordinary influence including obtaining state funding for the 2003 European Social Forum in Paris. Even after 2002 the Gaullist-led government, with its legacy of dirigisme, was unwilling to fully open France's doors to neoliberal globalization and the dictates of the market.

France's impressive social forum record is overshadowed by Italy which by 2006 had 227 entities identifying themselves as social forums. The hosting of the G8 summit in 2001 in Genoa and the first European Social Forum in Florence in 2002 clearly had a role in the development of social forum activism (della Porta 2003:11; Andretta and Mosca 2004; Reiter 2007). However, this does not fully explain the variation in impact of such stimuli since Britain has had both G8 summits and an ESF in London, yet little sustained or widespread social forum activism resulted. Clearly the ground has been more fertile in Italy and France.

In the case of Genoa, even before the decision of the WSF's IC to encourage regional forums, Italian organizers of the counter-summit had called it a social forum (Glasius 2005).

9 The focus here is on France and Italy for three reasons: 1) the high incidence of social forum activism; 2) differences in preferences for events versus processes or networks and 3) language limitations of the researchers. 
Many of the social forums in Italy referenced the Genoa and Florence events on their websites. These forums and their assemblies were modelled on types of direct, particularly, deliberative democracy. Data indicate that the majority of participants could be described as autonomists, alienated by traditional representative politics and parties (della Porta 2003: 12). Changes in Italy's political opportunity structure, in particular, the collapse of the Italian party system in the early 1990s liberated many organizations from their party allegiance (Reiter 2007) and served as a catalyst to the rise of a more independent and autonomist left.

The autonomists were strongly supportive of the social forum process and found themselves at odds with the more vertically-oriented radical elements within the organizing committees. Some claim this was a factor in the rather swift decline of the local social forum process in Italy. ${ }^{10}$ This conflict is reflected in the Rome Social Forum in 2002 where there was a "revolt" because the Coordinating Group was "prioritizing efficiency over discussion" (Rome ) [researcher's translation from Italian], and a struggle between the horizonals (autonomist) and verticals. The social forum process in Italy quickly mushroomed but many lasted for shorter periods than elsewhere and, in some cases, such as the Abruzzo Social Forum, were created primarily to promote local causes, such as the privatization of water.

\section{Social Forums in the Global South: South America beyond the WSF}

After Europe South America is the other major center of social forum activism, led by Brazil and Chile (in terms of the number of social forums) held. Brazil is clearly at the heart. The first three world forums were held there, as was the 2005 WSF. Brazil has also been the site for over 20 thematic forums, several trans-boundary regional forums, 24 sub-national forums and two national social forums. Given that several Brazilian organizations and activists were key founding members of the WSF this level of activism should come as no surprise. The links between the WSF, its Brazilian committee, and social forum activism are clear. How social forums have taken root, especially in affluent states, also reflects the changing political opportunity structure with local and national openings on the left and the strong support that leftist parties and other organizations have provided.

The largest number and earliest of sub-national forums, with the greatest attendance, were held in the state of Minais Gerais, heart of the populous (over 20 million) industrialized southeast. The role of place is reflected in the themes, attendance and the resources locals can draw upon including social movements, unions, NGOs, churches, the WSF Brazil Council, political parties, and supportive Worker's Party (PT) governments. For example, Belo Horizonte, the capital of Minais Gerais, has had a PT government for some time and uses participatory budgeting. This made it an obvious site to host the Forum Social Mineiro.

The roots of the Forum Social Mineiro are linked to the WSF and efforts by a group of university professors, unions and others to organize for the first WSF resulting in a 100 person delegation to Porto Alegre in 2001. This group also organized the first Forum Social Mineiro in September 2001 followed by others in 2002, 2004 and 2005. The same group became part of the WSF committee in the state and helped organize the BSF held in Belo Horizonte in 2003. Like many of the early forums in Brazil the Forum Social Mineiro hosted actions and campaigns focus

\footnotetext{
${ }^{10}$ This observation comes by way of a comment of an Italian activist to one of the authors at the 2007 World Social Forum in Nairobi, Kenya.
} 


\section{JOURNAL OF WORLD-SYSTEMS RESEARCH}

on opposing the Free Trade Area of the Americas (FTAA). The Forum Social Mineiro resembles the WSF in structure and process. Despite referencing the WSF principles, however, the open acceptance of participation by political parties in the organizing of the forum is distinctive and has not been accepted by the organizing committee of the BSF. One organizer interviewed was frank about the omnipresent role of political parties in the social forum process in Brazil and the hypocrisy of pretending they are at arm's length. The relationship between the parties and movements on the left in Brazil is a close one and parties are often seen as emanating from the movements (Santos 2004).

The first national Brazilian Social Forum in Belo Horizonte in November 2003 built upon the experiences of the Forum Social Mineiro. The council for the Brazilian Social Forum (BSF) is part of the WSF Brazil Council and represents a range of organizations including unions, such as Central Única dos Trabalhadores (CUT) and the landless workers movement (MST). The BSF in form looks very much like the WSF whose charter is referenced frequently in documents. The first BSF had 15,000 registered participants with 1200 organizations and over 300 activities organized around three themes: imperialism (the FTAA and external dependence); the Brazil that we have and the Brazil that we want; and the state and social movements.

The second BSF held in April 2006 followed the same pattern of being staged after a subnational forum had been held in the same location, in this instance the Northeastern Social Forum held in Recife in 2004. The second BSF also occurred during a year in which no World Social Forum was held. A different mix of participants reflected the region's poverty and historic settlements by former slaves. The organization of Afro-Brazilians, UNEGRO, had over 150 representatives. This forum was organized around a single theme, a discussion of the "political and institutional experiences in Brazil in the past few years" reflecting the corruption scandals of the Lula government and the run up to the fall election. (Brazilian social form http://www.fsb.org.br) Press coverage referred to the gathering as one of "activists for Reelection of Lula, but with reduced hopes” (Osava 2006).

Outside Belo Horizonte sub-national forums have been held across Brazil. What is particularly interesting about those held in the north-eastern state of Rio Grande do Norte in 2002, 2003, and 2004 is their origins in small groups of activists, particularly feminists (connected to the World March of Women) who attended the first WSF.

We also sought to examine social forum activism in the rest of South America, how and where it diffused and the role of political opportunity structures. We decided to examine Chile because it has had the second highest number of social forums in Latin America, although Argentina comes a close second at 15, followed by Uruguay with 8.

\section{Social Forums in Chile}

Two national forums were held in Chile in 2004 and 2006, along with three thematic forums on education, democracy and social work in 2005 and 2006, all of them in Santiago. In addition we found eleven sub-national forums, most occurring in 2004-6.

The stimulus for the first national social forum in 2004 was external, the summit of the Asia-Pacific Economic Forum for Economic Cooperation (APEC) in Santiago and the desire to organize a counter space of resistance to neo-liberalism during the meeting. The opening march had over 60,000 participants with 8,000 registered and 200 organizations including environmental groups, labor unions, church organizations, women's groups and ATTAC. Funding came from 
NGOs, including Greenpeace, ATTAC, Amnesty International, some churches and Swedish aid groups. Themes included Latin-American integration, Free Trade Agreements, Environmental Sustainability, Democracy, Sovereignty and Globalization, Human Development and World Peace, Native People and Cultural Diversity. In contrast the 2006 event was smaller with 3000 participants and 140 activities.

An example of a local forum was one held in Araucanía in 2006. This region of southern Chile is home to the Mapuche people, the country's main indigenous group. It has a high level of poverty and struggles centre around resource development. Those involved in the Araucanía SF had first met at a forum held in southern Chile. The 2006 event had 300 participants and 30 organizations involved including indigenous groups and institutes, Mapuche communities and environmental rights groups. Environmental organizations, a foundation, and local university provided support along with Le Monde Diplomatique Chile, and the European Union. The themes addressed the situation of the Mapuche people, the environment and biodiversity, democracy, development, the economy and the media. The goals of the forum included building stronger social networks in the region but also raising awareness of the situation of the Mapuche people and countering the national media's negative stereotyping of them as "criminals."

The contrast with the national forum is evident. The latter had been stimulated by and addressed the broader struggles over economic integration into the global neo-liberal economy and externally-linked events, especially the APEC summit and the FTA with the US. The Araucanía SF in contrast was diffused through locals who brought social forum activism back to their community and focused it around their identity and the plight of indigenous people.

Despite higher per capita incomes than Brazil social forum activism in Chile came much later, as a reaction to struggles over economic integration; a reflection in itself of a weaker left and political regimes which have embraced neo-liberalism. Chile's governments, even after the departure of Pinochet in 1989, have continued to take the country in a neo-liberal direction, as reflected in the US-Chile Free Trade Agreement which came into effect on January 1, $2004{ }^{11}$

From the very outset WSF organizers recognized that the Latin American and European dominance was problematic and that those most marginalized by neo-liberal globalization were in the regions least well represented within the social forum process, especially Asia and Africa (Santos 2004). Thus began an active effort to diffuse social forum activism more widely.

\section{Social Forum Outreach in Asia}

The WSF's International Council had addressed the uneven participation in social forums early on and recognized that India, given its size, poverty, and civil society tradition of activism should be more represented in the social forum process. The IC's main tool of transmission is through

${ }^{11}$ The centre left coalition of socialist and Christian democratic parties which has held power since 1990 has continued to embrace neo-liberalism and though the new female socialist president Michelle Bachelet won for the coalition with 53 per cent of the vote in a run-off in 2006 her policies indicate continuity (Bonnefoy) with marginal changes in terms of addressing very high levels of inequality. As Klein and others point out this is very much the residue of the shock of 9/11 in 1973 in Chile. 


\section{JOURNAL OF WORLD-SYSTEMS RESEARCH}

stimulating and facilitating forum events, not transferring major financial resources. ${ }^{12}$ The IC sought to stimulate Indian participation through regional events but also by moving the WSF there. (Leite 2005) However, concerns about the capacity of the Indian organizing committee and the reluctance of some within the IC to move the WSF led to the decision to, first, hold an Asian Social Forum in India.

The Asian Social Forum in Hyderabad, Andra Pradesh, in January 2003 attracted over 15,000 delegates from 80 countries. Most were drawn from India and South Asia, partly because the rightwing, pro-globalization Bhratiya Janata Party (BJP) government delayed granting visas to many international delegates. Shortly thereafter the IC made the decision that Mumbai would host the 2004 WSF. According to the WSF secretariat 74,126 registered for the January 2004 forum representing 1,653 organizations from 117 countries. Other estimates put participation on site at over 130,000. Holding the WSF in Mumbai is credited too with the strong presence of South Asians at the WSF in Porto Alegre a year later (IBASE 2006).

This success led to a decision to hold the third WSF polycentric forum in 2006 in Karachi, Pakistan. Delayed because of the earthquake it was held March 24-29, with attendance of over 30,000. Taking place in a country under a military regime and on the front line of the war on terror yet still incorporating the energy that had been observed in Mumbai was considered impressive (Rousset 2006). While 58 countries were represented most participants again came from the region.

In both India and Pakistan the regional and world forums resulted in strong mobilization of activists within the global process, such as the Dalits who have attended subsequent WSFs in Porto Alegre and Nairobi and formed important linkages with other groups and transnational networks (Smith 2008). What is striking, however, is that there has not been a blossoming of national or sub-national forums similar to Europe and Latin America. India has to date held only one national forum in Delhi in 2006. Pakistan formed an organization in 2003 and held one national forum in Lahore in 2004, not surprising perhaps given the nature of its political opportunity structure, in contrast to India.

Beyond the WSF outreach efforts, only a few pockets of national social forums emerged in Asia and there are some puzzling absences. Observers have noted the role that Southeast Asian groups have been playing, especially since the financial crisis of 1997, in the transnational networks challenging neoliberal globalization. Groups from South Korea, the Philippines, Thailand and Malaysia have been active opponents of the World Trade Organization (WTO) and bilateral and regional trade agreements (Caouette 2006). South Korean union and peasant organizations have used WSF meetings in 2003 and 2005 to network with other groups in coordinated opposition to WTO ministerial meetings in Cancún, Mexico and Hong Kong. Groups in this region, as Couette points out, have played an important role in knowledge production about globalization and its impact and have been key global network builders. Moreover, within the WSF organizations, such as Focus on the Global South based in Thailand, have been central within networks dealing with trade issues (Anheier and Katz 2005). Yet, aside from South Korea, which has held a national social forum every year since 2002, there is little evidence of social

\footnotetext{
${ }^{12}$ Raising resources is the responsibility of the local organizing committee. Most often they are composed of foundation funds, registration fees and contributions from various NGOs and aid agencies. Dependence on a few large donors has generated controversy especially in Mumbai and led to a report commissioned by the WSF IC. See Lopez et al 2006.
} 
forum activism at the regional, national or sub-national level. The role of limited political space and opportunity here clearly merits further investigation.

In contrast, as we indicate below, the most marginalized region, Africa, which has also been the target of WSF efforts to stimulate social forum activism, has exhibited, though modest, a variety of social forum activism at various levels.

\section{Social Forum Outreach, Africa}

Africa is the continent the most victimized by globalization. With over 900 million people and 53 states Africa is overrepresented in UN poverty data. The UN Human Development Index ranks 23 sub-Saharan African states at the bottom of 177 countries. Of the 50 UN-designated least developed countries 35 are in Africa. Given limited resources, weak civil society and basic struggles in a number of countries we might expect to find a smaller number of forums. That is the case in comparison to numbers within Europe and South America. Yet there is wide diversity in the number of forums in various areas. The WSF's IC has played a key role in transmission.

Recognizing both the need for, and challenges of, developing a social forum process in Africa the IC actively supported the development of the first African Social Forum. Led by two well-known activists, a former Mali minister of culture, and member of the IC, and the head of a Senegal-based NGO (ENDA) it was held in January 2002 in Bamako, Mali. This was followed by continental forums in 2003 (Addis Ababa), 2004 (Lusaka) and 2005 (Conakry). In addition the IC chose Bamako to host one of three polycentric WSFs in 2006 and Nairobi, Kenya for the global WSF in 2007. The link to the global WSF process is a very direct one.

To date there have been 62 forums in total on the continent including several global, continental and regional events, as well as thematic forums. Regional ones include:

\begin{tabular}{lrl}
\hline West African SF & 2004 & Conakry, Guinea \\
& 2005 & Coutonu, Benin \\
Southern Africa & 2003 & Luskake, Zambia \\
& 2005 & Harare, Zimbabwe \\
Magreb & 2006 & Morocco \\
\hline
\end{tabular}

Another 50 have occurred at the national and sub-national levels. The breakdown of our data for forums at the national and local levels is as follows: 


\section{JOURNAL OF WORLD-SYSTEMS RESEARCH}

Table 4: African Social Forums-National, Sub-national and Local

\begin{tabular}{llll} 
Country & Number & Country & Number \\
\hline Algeria & 1 & Morocco & 4 \\
Benin & & & \\
Cameroon & 1 & Niger & 3 \\
Central African Rep. & 3 & Nigeria & 2 \\
Guinea $^{2}$ & 1 & Senegal & 3 \\
Ivory Coast $_{\text {Kenya }}^{3}$ & 2 & Somalia & 3 \\
Mali $^{4}$ & 3 & South Africa (Durban) & 1 \\
Malawi $_{\text {Mozambique }}$ & 4 & Tanzania & 2 \\
& 6 & Tunisia & 1 \\
& 2 & Uganda & 2 \\
\hline
\end{tabular}

1. Benin has also hosted a West African Social Forum

2. Guinea also hosted an African and a West African Social Forum

3. Kenya has also hosted 3 thematic forums and the WSF in 2007 Zambia has also hosted an

4. Mali has also hosted a thematic Cotton forum and an African and a World Social Forum (polycentric)

5. Morocco has also hosted a Magreb Social Forum

6. African and a Southern African Social Forum

7. Zimbabwe has also hosted a Southern African Forum

South Africa and Nigeria, given their size and significance in Sub-Saharan Africa, have seen the development of few forums, although the ones held in Nigeria attracted large numbers for Africa. The hotbeds of local social forum activism, Mali and Kenya, may be linked to earlier experiences hosting major forums, in Mali's case the first ASF. The first Kenyan social forum was held in 2003. The presence of a UN agency and a stronger NGO base might account too for Kenya's numbers. Where forums occur is clearly not directly tied to local resources. Niger, which ranks last on the UN Human Development Index has had three forums, the first in 2003 had over 700 participants. ${ }^{13}$ In this instance, as in other African countries outside support and resources often from development NGOs, ${ }^{14}$ aid agencies and foundations has been important.

Like Niger, Mozambique ranks low in 168th place on the Human Development Index and having experienced civil war and floods seems an unlikely place to expect a social forum. Yet one was held in October 2006. The Mozambique case illustrates the importance of the WSF personal experience and the link of the Portuguese language in stimulating individual activists at the local level. The participation of several of its founders in the WSF in 2002 in Porto Alegre

${ }^{13}$ One of the Quebec organizations most active in social forums, Alternatives, supported and helped fund the participation of groups in the Niger SF. The number of Canadians involved in West African SFs may be the result of the higher level of French-speaking Quebec NGOs in this region.

${ }^{14}$ Via Campesina has been active, for example, in Mali. (George, 2007) 
stimulated local organizing efforts in 2002 and the creation of a committee. An assembly and the election of a national council followed in 2005. Held in Maputo in October 2006 the social forum had 200-300 participants and was intended to create stronger links among groups and prepare for participation in the WSF in Kenya. While organizers felt the event was a success the challenges of mobilizing financial resources accounted for its slow gestation and some of the organizational problems.

Our African data suggest that efforts to stimulate social forum activism and networks have had some success but remains, as does much of social forum activism in marginalized regions within and across countries, heavily dependent on external, especially financial, resources. Often provided by foundations, large NGOs and state aid agencies this assistance is not without controversy and risks limiting and shaping the nature and extent of resistance to neo liberal globalization in these places.

\section{CONCLUSION}

Our sketches of multi-level social forum activism on various continents show a diverse range of activities and networks. They provide a rich set of data which offers insights into the way in which innovative practices of collective action are diffused. They also show the importance of place in how and where such practices become imbedded. The data have the potential, in the interesting patterns they reveal, to further our understanding of how the global and local link in collective action to challenge neo-liberal globalization.

Given the role of Brazilian and French organizations like ATTAC in creating the WSF the strength of social forum activism in France and Brazil should come as no surprise. The timing of its emergence also points to the role of political opportunity structures which, in both France and Brazil, provided space for these organizations to flourish and mobilize resources. The key direct channel of diffusion of social forum activism has been through the processes and structures they created, especially the decisions and actions of the International Council of the WSF and the secretariat which have stimulated and supported social forum activism, particularly in peripheral regions. The experiences of activists who bring social forum practices from the WSF back to their "home" has also been a channel of diffusion often facilitated by shared language or culture, as is the case in Quebec and Mozambique. Major events (such as the Genoa G8) and a shared identification or link to the master frame of resistance to neo-liberal globalization have also been sources of social forum activism.

Successful diffusion is not guaranteed however. The IC itself has recognized this in a report on the financial challenges of rapid growth in the size of the WSF event and the spread of social forums:

According to many (IC members) who were interviewed, real internationalisation has not occurred yet, only geographical expansion. Even though geographical expansion is part of internationalisation, in terms of wider internationalism ownership is still wanting..... Even in terms of geography, the absence of Eastern Europe, Indonesia, Malaysia, China and large parts of the Arab world is very well noticed. According to them, ownership of the WSF needs to be internationalised more (Lopez 2006:14). 


\section{JOURNAL OF WORLD-SYSTEMS RESEARCH}

Adoption may be very dependent on the resources (both internal and external) available to be mobilized, the political opportunity structure, the strength and unity of local social movements and organizations and the extent to which social forum practices resonate locally. While mechanisms of diffusion might sow the seeds they do not ensure that the garden will grow.

The rich diversity in the extent and forms of social forum activism around the world also points to the importance of place and context. A deeper understanding of these differences and how the global is linked and adapted to the local level will require more collaborative and comparative research with an emphasis on the specifics of place.

The emergence of so many national and sub-national forums suggests the importance of "rooted cosmopolitans" with flexible identities who, while grounded in the local context, engage in, or are part of, transnational networks struggling against neo-liberalism (Tarrow and della Porta 2005: 237). The localness of the social forum activism we have identified and the diversity of responses which globalization stimulates also raise questions about a unified and programmatic global response to neo-liberalism. It reminds us too as scholars that, as mesmerizing as the WSF may be, the front line in this struggle is local.

\section{REFERENCES}

Abruzzo Social Forum. (2006). "Forum Report Back," Retrieved November 3, 2007.(http://www.abruzzosocialforum.org/)

Andretta, Massimiliano and Lorenzo Mosca. 2004. "Understanding the Genoa Protest." Pp.43110 in Creating a Better World: Interpreting Global Civil Society edited by Rupert Taylor. Bloomfield, CT: Kumarian Press.

Anheier, Helmut and Hagai Katz. 2005. "Networks Approaches to Global Civil Society.” Pp.206221 in Global Civil Society 2004-5 edited by Helmut Anheier, Marlies Glasius and Mary Kaldor. London: Sage.

Ayres, Jeffrey. 1998. Defying Conventional Wisdom. Toronto: University of Toronto Press.

Becker, Marc .2006. “Marc's Blog.” Midwest Social Forum. Retrieved February 10, 2007 (http://www.mwsocialforum.org/node/1100 October 23,2006)

Brazilian Social Forum www.fsb.org retrieved February 2, 2007.

Center for Communication and Civic Engagement. 2007. "Which way for the Northwest Social Forum? A dialogue on cross-issue organizing." Seattle, Washington: University of Washington (July 7) www.engagedcitizen.org/nwsf.

Chabot, Sean. 2001. "Transnational Diffusion and the African American Reinvention of Gandhian Repertoire.” Mobilization 5: 201-216.

Chabot, Sean and Jan Willem Duyvendak. 2002. "Globalization and transnational diffusion between social movements: Reconceptualizing the Dissemination of the Gandhian repertoire and the "coming out" routine." Theory and Society 31:697-740.

Chase-Dunn, Christopher, Christine Petit, Richard Niemeyer, Robert A. Hanneman, Rebecca Giem, Erika Gutierrez and Ellen Reese. 2006. "The Contours of Solidarity and Division Among Global Movements” Paper presented at the American Sociological Association meeting in Montreal, Canada.

Chilean Social Forum: http://www.forosocialchile.cl. Retrieved February 10, 2007. 
Caouette, Dominique. 2006. "Thinking and Nurturing Transnational Activism: Citizen Advocacy in Southeast Asia.” Kasarinlan, Philippine Journal of Third World Studies 21:3-33.

Conway, Janet. 2006 "The global diffusion of the World Social Forum: the politics of place and scale, a view from Canada." translated and published as: "La Difusión Global del Foro Social Mundial: La Política de Lugar y Escala Vista Desde Canada.” Pp. 77-89In El Foro Social Mundial: Un Camino a un Mundo Nuevo, edited by Frank Bracho. Caracas, Venezuela: Fondo Edition Question.

della Porta, Donatella. 2003 "Democracy in Movement: Organizational Dilemmas and Globalization from Below" Colloque "Les Mobilisations Altermondialistses” 3-5 December. European University Institute, retrieved February 7, 2007.

della Porta, Donatella and Sidney Tarrow. 2005. "Conclusion” in Transnational Protest and Global Activism, Pp. 223-238(pages) edited by Donatella della Porta and Sidney Tarrow. Lanham: Rowman and Littlefield

Donohue, Sean. 2004. “The Dems aren't the Only Show in Beantown” Retrieved February 3, 2007 (http://www.counterpunch.org/donahue07072004.html)

Dufour, Pascale. 2003. "Globalisation as a New Political Space: The End of the Quebec-Quebec Debate.” Paper Presented for the Conference "Quebec and Canada in the New Century: New Dynamics, New Opportunities. Kingston: Queen’s University.

Ervamaa, Suvi. 2005. "The Diffusion of Political Ideas in Space and Time The Case of Alterglobalist Movement in Finland" paper presented at the Politics of Participation Focus on the 'Third Sector' Helsinki, August 25-27.

Gironde Social Forum. 2006 http://www.fsl33.net/article.php3?id_article=279 retrieved September 28, 2006.

Glasius, Marlies. 2005. "Deliberation or Struggle? Civil Society Traditions Behind the Social Forums.” Ephemera 5:240-252.

Glasius, Marlies and Jill Timms.2006. "Social Forums: Radical Beacon or Strategic Infrastructure.” Pp. 196-240 in Global Civil Society 2005/6, edited by Marlies Glasius, Mary Kaldor, Helmut Anheier. London: Sage.

Hadden, Jennifer and Sidney Tarrow 2007 "The Global Justice Movement in the United States." Pp. 210-232 in The Global Justice Movement: Cross-National and Transnational Perspectives. edited by Donatella della Porta. Boulder: Paradigm.

IBASE. 2006. "The World Social Forum: An X-ray of participation in the 2005 Forum: Elements for Debate.” (www.ibase.br) retrieved February 22, 2007.

IBASE. 2006. "The World Social Forum: An X-ray of participation in the polycentric forum, 2006, Caracas and Bamako chapters.” (www.ibase.br) retrieved February 22, 2007.

Icaza, Rosalba. 2008. Personal Communication to P.J. Smith, 8 December 2008- e-mail,

Juris, Jeffrey. 2007. "Where are the Americans? Comparing Mobilization Dynamics across the Social Forums" Paper presented at the annual meeting of the International Studies Association 48th Annual Convention, 2007-02-28.

Juris, Jeffrey. 2008. Networking Futures: The Movements against Corporate Globalization. Durham, NC: Duke University Press.

Klein, Naomi. 2007. The Shock Doctrine, the Rise of Disaster Capitalism. Toronto: Knopf.

Kolb, Felix. 2005. "Mass Media and the Making of ATTAC Germany." Pp. 95-120 in Transnational Protest and Global Activism, edited by Donatella della Porta and Sidney Tarrow. New York: Rowman and Littlefield. 
La Botz, Dan. 2005. “Mexico’s Labor Movement in Transition” Monthly Review 57:62-72.

Leite, Jose Corrêa. 2005. The World Social Forum: Strategies of Resistance. Chicago: Haymarket Books.

Lee, Julian. 2004, “The European Social Forum at 3: Facing Old Challenges to Go Forward” http://www.casin.ch/web/pdf/europeansocialforum2004.pdf Retrieved February 7, 2007.

Lopez, Rolando et al. 2006. World Social Forum Financial Strategy

Report and Recommendations to the International Committee (September)forumsocialmundial.org.br/download/WSF_finstrategy_FinalReport_

FR.pdfwhere retreived November 4, 2007.

McAdam, Doug. 1996. "Political Opportunities: Conceptual Origins, Current Problems, Future Directions." Pp. 23-40 in Comparative Perspectives on Social Movements. edited by Doug McAdam, John D. McCarthy, and Mayer Zald. Cambridge: Cambridge University Press.

Meyer, David S. 2004. "Protest and Political Opportunities.” Annual Review of Sociology 30:125145.

Mozambique Social Forum: http://www.fsmoc.org.mz/ retrieved June 24, 2007.

Osava, Mario. 2006. “Activists for Re-election of Lula, but With Reduced Hopes.” Inter-Press Service, April 24. http://www.globalexchange.org/countries/brazil/3906.html retrieved September 28, 2006. Pianta, Mario. 2005 "UN World Summits and Civil Society: The State of the Art."

United Nations Research Institute for Social Development (UNSRID) Programme Papers on Civil Society and Social Movements,18, August. www.unrisd.org/UNRISD/website/document.nsf retrieved September 28, 2006.

Pramas, Jason. 2004. "Challenge and Promise of the Boston Social Forum.” Retrieved February 3 2007 (http://www.peaceworkmagazine.org/pwork/0406/040615.htm,)

Quintana S., Victor M. 2006. “Mexico’s Short Summer of Democracy,” IRC Americas special report . December 1, 2006. pp. 1-5, http://americas.irc-online.org/am/3746 retrieved June 24, 2007.

Reiter, Herbert, Massimilano Andretta, Donatella della Porta, and Lorenzo Mosca. 2007. "The Global Justice Movement in Italy.” Pp. 52-79 in The Global Justice Movement: CrossNational and Transnational Perspectives edited by Donatella della Porta, Boulder: Paradigm.

Rome Social Forum. 2002. http://www.mir.it/g8/2002/20021021/3db427a08530d.html Retrieved November 3, 2007.

Rousset, Pierre. 2006. "The Karachi Social Forum and its International Significance." International Viewpoint Online Magazine (April) also available on WSF website, www.forumsocialmundial.org.br.

Santos, Boaventure de Sousa. 2004. "The World Social Forum: A Users Manual” Madison: University of Wisconsin http:www.ces.uc.pt.bss/documentos.fsm_eng.pdf. retrieved July 10, 2007. 
Smith, Jackie. 2008. Social Movements for Global Democracy Baltimore: Johns Hopkins University Press (chapter 12)

Smith, Jackie. 2004. "Transnational Processes and Movements.” Pp. 311-335 in The Blackwell Companion to Social Movements, edited by David A, Snow, Sarah Soule and Hanspeter Kriesi. Oxford: Blackwell.

Smith, Jackie, Jeffrey Juris and the Social Forum Research Collective . 2008 "We Are the Ones We have been Waiting for: The US Social Forum in Context.” Mobilization December, 2008. 13:373-394.

Smith, Miriam. 2005. A Civil Society. Peterborough, Ontario, Canada: Broadview Press.

Smith, Peter J. 2008. "Going Global: The Transnational Politics of the Dalit Movement." Globalizations, 5:13-33.

Sommier, Isabelle and Hélène Combes. 2007. “The Global Justice Movement in France.” Pp. 103-128 in The Global Justice Movement: Cross-National and Transnational Perspectives edited by Donatella della Porta. Boulder: Paradigm Publishers.

Soule, Sarah. H. 2003. "Diffusion Processes Within and Across Movements.” Pp. 294-310in The Blackwell Companion to Social Movements, edited by David Snow, Sarah Houle and Hanspeter Kriesi. Oxford: Blackwell.

Tarrow, Sidney and Doug McAdam. 2005. "Scale Shift in Transnational Contention.” Pp. 121147 in Transnational Protest and Global Activism, edited by Donatella Della Porta and Sidney Tarrow. Lanham: Rowman and Littlefield.

Wallerstein, Immanuel (2008) "Mexico - What Have the Zapatistas Accomplished?" Commentary posted online. Retrieved 3, 2008 (www.alterinfos.org/spip.php?article1907)

Waters, Sara. 2004. "Mobilising against Globalisation: ATTAC and the French Intellectuals." West European Politics 27:854 - 874. 